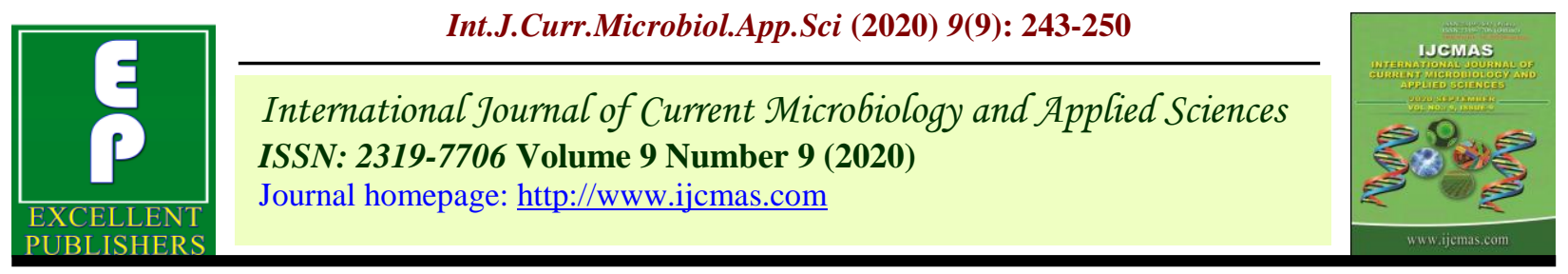

Original Research Article

https://doi.org/10.20546/ijcmas.2020.909.030

\title{
Influence of Chitosan Foliar Application on Quality and Biochemical Traits of Strawberry (Fragaria $\times$ ananassa Duch.) under Naturally Ventilated Polyhouse
}

\author{
K. M. Nithin ${ }^{1 *}$, D. Madaiah ${ }^{2}$, B. S. Shivakumar ${ }^{3}$, \\ M. Dinesh Kumar ${ }^{4}$ and B. C. Dhananjaya ${ }^{5}$ \\ ${ }^{1}$ Department of Fruit Science, ${ }^{2}$ Department of Postharvest Technology, ${ }^{3}$ Department of Fruit \\ Science, College of Horticulture, Mudigere, Karnataka, India \\ ${ }^{4}$ Department of Agronomy, College of Agriculture, ${ }^{5}$ Department of Soil Science and \\ Agricultural Chemistry, Shivamogga, Karnataka, India \\ *Corresponding author
}

\section{A B S T R A C T}

\begin{tabular}{|l|}
\hline Ke y w o r d s \\
$\begin{array}{l}\text { Berry, Chitosan, } \\
\text { Media, Poly house } \\
\text { and Strawberry }\end{array}$ \\
\hline Article Info \\
\hline $\begin{array}{l}\text { Accepted: } \\
\text { 04 August } 2020 \\
\text { Available Online: } \\
\text { 10 September } 2020\end{array}$ \\
\hline
\end{tabular}

An experiment was conducted to know the effect of foliar application of chitosan with different concentrations and number of applications (once, twice and three times) on quality and biochemical traits of strawberry (var. Winter Dawn) during 2019-2020. Among the treatments tested,Chitosan spray $3 \mathrm{~g} \mathrm{l}^{-1}$ at 45, 90 and 135 DAP recorded comparatively better biochemical traits of fruit viz., Total Soluble Solids (7.96 Brix), chlorophyll-a $\left(1.85 \mathrm{mg} \mathrm{g}^{-1}\right)$, chlorophyll-b $\left(0.59 \mathrm{mg} \mathrm{g}^{-1}\right)$ and decreased physiological loss in weight (PLW) (3.45\%). On the contrary, Chitosan spray $2 \mathrm{~g} \mathrm{l}^{-1}$ at 45,90 and 135 DAP recorded maximum reducing sugar $(4.79 \%)$, non-reducing sugar $(1.65 \%)$, total sugar $(6.44 \%)$ and antioxidants $\left(413.42 \mu \mathrm{g}\right.$ BHT g $\mathrm{g}^{-1}$ fruit). While the ascorbic acid (53.29 $\mathrm{mg}$ $\left.100 \mathrm{~g}^{-1}\right)$ and anthocyanin content $\left(54.69 \mathrm{mg} 100 \mathrm{~g}^{-1}\right)$ found maximum in Chitosan spray 3 $\mathrm{g}^{-1}$ at 45 DAP with minimum titratable acidity $(0.86 \%)$. From this study, it was concluded that foliar application of chitosan thrice at $3 \mathrm{~g} \mathrm{l}^{-1}$ with 45 days interval was found better (fruit yield per plant $366.17 \mathrm{~g}$ ) followed by foliar application of chitosan

\section{Introduction}

Strawberry (Fragaria $\times$ ananassa Duch) a genus of the Rosaceae family, is the most commonly consumed berry fruit crop worldwide and is valued for its unique flavour and nutritional quality. Strawberry is an important fruit crop of India and its commercial production is possible in temperate and sub-tropical areas of the country. It is an herbaceous perennial and short-day plant having short stem known as crown. The edible portion includes the ripened receptacle and achenes (true fruits and seed) and usually propagated through runners. Strawberry is one of the unique fruits among the cultivated temperate fruits. It is the quickest plant to produce fruit from the time of planting and is the earliest fruit to come to the market in the spring (Jackson et al., 2011). 
Strawberries have been one of the outstanding successful crops of India. High crop yield and early harvests are of primary importance to the growers, while fruit quality is most important to the consumers. However, strawberries have a short postharvest life with rapid spoilage, reflecting high susceptibility to mechanical injury, excessive texture softening, physiological disorders and infection through several pathogens during production, transport, storage and processing. These lacunas can be overcome by the application of new technologies which resulted in rapid advances in Indian strawberry industry. However, advances and improvement in this trend must continue and more environmental friendly production must be followed. Some eco-friendly products that has been widely used in agricultural applications is Chitosan.

Chitosan, a deacetylated biopolymeric derivate of chitin, is a high molecular weight cationic linear polysaccharide composed of randomly distributed $\beta$-1,4-linked $\mathrm{D}$ glucosamine (deacetylated unit) and to a lesser extent, N-acetyl-D-glucosamine (acetylated unit).It is a polysaccharide called 2-Amino-2-deoxybeta-D-glucosamine

(Peniston and Johnson, 1980). Chitosan can be extracted from the marine crustacean like shrimps, cramp and pinfish or from the exoskeletons of most insects under the name of chitin which can be transformed into chitosan by extracting the acetyl group and turn it into amino (Sugiyama et al., 2001).It is considered as an environment-friendly for agricultural uses, as it is easily degraded in the environment and non-toxic to humans. Chitosan have antimicrobial activities against various phyto-pathogens and enhancement of storability and preservation of anthocyanin content in chitosan-coated strawberry fruit has been reported from multiple studies (Malerba and Cerena, 2018 and El-Ghaouth et al., 1992). Chitosan has been widely used as a coating agent of various fruit mainly for protection from postharvest losses due to microbial infections (Sakif et al., 2016). Chitosan has been widely used in agricultural applications mainly for stimulation of plant defense $(\mathrm{Yu}$ and Meuhlbauer, 2001; Hadwiger et al., 2002; Bautista-Banos et al., 2003 and Naeem et al., 2010). Considering the potential uses of chitosan for enhancing plant growth, yield, quality and biochemical traits of fruits the present study was conducted to the influence of foliar application of chitosan on fruit quality and biochemical traits of strawberry.

\section{Materials and Methods}

Experiment was conducted in a naturally ventilated polyhouse of the Department of Fruit Science, College of Horticulture, Mudigere, during 2019-2020. Mudigere is situated in the Western Ghats, represents the typical climate of Hill zone (Zone- 9 and Region- V) of Karnataka. It is located at $13^{\circ} 7^{\prime}$ North latitude and $74^{\circ} 37^{\prime}$ East longitude with an altitude of $980 \mathrm{~m}$ above mean sea level (MSL). The design applied for the study was Completely Randomized Design (CRD) with three replications and twelve treatments. The experiment was conducted in plastic trays of size $60 \times 20 \times 15 \mathrm{~cm}$. The trays were filled with media viz., Soil: Vermicompost: Vermiculite: Cocopeat in the ratio of $1: 1: 1: 1$ on volume (v/v) basis (Fig. 1). The test variety was "winter dawn" and the planting was taken up on $7^{\text {th }}$ November 2019.

Practical grade of chitosan biopolymer (poly $\beta$-1, 4-D-glucosamine) which has the degree of de-acetylation to the extent of 75 per cent with low viscosity was procured for the study. Three different concentrations 1000, 2000 and $3000 \mathrm{ppm}$ were prepared by dissolving $0.1 \mathrm{~N}$ $\mathrm{HCl}$ and diluting with distilled water and adjusted at 6.5 by $0.1 \mathrm{~N} \mathrm{NaOH}$ (Benhamou $e t$ $a l .$, 1998). Freshly prepared chitosan solutions 
were applied onto strawberry plants in each experimental unit prior to flowering, at 50 Per cent flowering stage and at fruit development stage once, twice and thrice with respect to treatments by spraying up to run off in three different times with 45-days intervals starting from November 07, 2019 to March10, 2020. Plants in the control plots were sprayed with equal volume of deionized distill water amended with equal volume of $0.1 \mathrm{~N} \mathrm{HCl}$ and $\mathrm{NaOH}$ for adjusting $\mathrm{pH}$ at 6.5 (without chitosan).

The different chitosan concentrations and application frequency based treatment combination includes $\mathrm{T}_{1}$-Water spray at 45 DAP, $T_{2}$-Water spray at 45 and 90 DAP, $T_{3}$ Water spray at 45, 90 and $135 \mathrm{DAP}^{-} \mathrm{T}_{4}$ Chitosan spray $1 \mathrm{~g} \mathrm{l}^{-1}$ at $45 \mathrm{DAP}, \mathrm{T}_{5}$-Chitosan spray $1 \mathrm{~g} \mathrm{l}^{-1}$ at 45 and $90 \mathrm{DAP}, \mathrm{T}_{6}$-Chitosan spray $1 \mathrm{~g} \mathrm{l}^{-1}$ at 45,90 and $135 \mathrm{DAP}, \mathrm{T}_{7^{-}}$ Chitosan spray $2 \mathrm{~g} \mathrm{l}^{-1}$ at $45 \mathrm{DAP}, \mathrm{T}_{8}$-Chitosan spray $2 \mathrm{~g} \mathrm{l}^{-1}$ at 45 and $90 \mathrm{DAP}, \mathrm{T}_{9}$-Chitosan spray $2 \mathrm{~g} \mathrm{l}^{-1}$ at 45,90 and $135 \mathrm{DAP}, \mathrm{T}_{10^{-}}$ Chitosan spray $3 \mathrm{~g} \mathrm{l}^{-1}$ at $45 \mathrm{DAP}, \mathrm{T}_{11^{-}}$ Chitosan spray $3 \mathrm{~g} \mathrm{l}^{-1}$ at 45, 90 DAP and $\mathrm{T}_{12-}$ Chitosan spray $3 \mathrm{~g} \mathrm{l}^{-1}$ at 45, 90 and 135 DAP. Different quality and biochemical parameters of straw beery fruits were analyzed by adopting standard procedures. The different quality and biochemical traits includes Total Soluble Solids, leaf chlorophyll content, reducing sugar, non-reducing sugar, titratable acidity, ascorbic acid, anthocyanin, antioxidant contents, physiological loss in weight and shelf life. The data subjected to statistical analysis for drawing conclusion $(\mathrm{p}=5 \%)$ as per Fisher and Yates (1963).

\section{Results and Discussion}

Foliar application of chitosan at different concentrations and application frequencies significantly influenced the fruit quality parameters of strawberry (Table 1\&2). Different treatments in test recorded 6.14
$7.96{ }^{0} \mathrm{~B}$ total soluble solids (TSS). Application of different concentrations of chitosan improved the TSS content. Among the treatments, foliar application of chitosan 2 $\mathrm{g}^{-1}$ or $3 \mathrm{~g} \mathrm{l}^{-1}$ thrice at 45 days interval significantly higher TSS (7.84 and $7.96{ }^{\circ} \mathrm{B}$ respectively). On the similar lines, lowest and highest chlorophyll-a (1.43 and1.85 mg/ g respectively), chlorophyll-b (0.46 and 0.59 $\mathrm{mgg}^{-1}$ respectively) and total chlorophyll (1.89 and $2.44 \mathrm{mgg}^{-1}$ respectively) was recorded respectively in water or chitosan spray $3 \mathrm{~g} \mathrm{l}^{-1}$ thrice at 45 days interval. This increase in TSS could reflect the cell wall disassembly (Cordenusi et al., 2005), the decrease in respiration rate and increase in dry matter due to water loss (Dris and Niskanen, 1999). The lower TSS values might reflect dilution of sugars by spray of water during fruit ripening. The similar results were also obtained by Petriccione et al., (2015).

Shelf life of a fruit is subjected to physical conditions of the fruit and also its surrounding environment. Strawberry fruits are highly susceptible to a rapid loss of water due to the extreme thin skin of the fruits. The loss of weight in fresh fruit primarily reflects the respiration rate and moisture evaporation between the fruit tissue and surrounding air (Hernandez-Munoz et al., 2006). In the present study, Chitosan application improved shelf life while decreased the physiological loss in weight (PLW) of fruits. Study revealed that application of chitosan spray $3 \mathrm{~g} \mathrm{l}^{-1}$ thrice at 45 days interval improved the shelf life to 3.93 days from 1.81 days (Water spray) and decrease the PLW to 3.45 per cent from 9.61 per cent. The possible reason for decrease in PLW of fruits was chitosan acts as a semipermeable barrier against oxygen, carbon dioxide and moisture thereby reducing respiration and water loss and counteracting the dehydration and shrinkage of fruit during storage. 
Table.1 Effect of chitosan foliar application on quality, leaf chlorophyll content and yield of strawberry under naturally ventilated playhouse

\begin{tabular}{|c|c|c|c|c|c|c|c|}
\hline \multirow[t]{2}{*}{ Treatment } & \multirow{2}{*}{$\begin{array}{c}\text { TSS } \\
\left({ }^{\circ} \text { Brix }\right)\end{array}$} & \multirow{2}{*}{$\begin{array}{c}\text { Physiological } \\
\text { loss in weight } \\
(\%)\end{array}$} & \multirow{2}{*}{$\begin{array}{c}\text { Shelf } \\
\text { life } \\
\text { (days) }\end{array}$} & \multicolumn{3}{|c|}{ Chlorophyll content $\left(\mathrm{mgg}^{-1}\right)$} & \multirow{2}{*}{$\begin{array}{l}\text { Yield per } \\
\text { plant (g) }\end{array}$} \\
\hline & & & & $\begin{array}{c}\text { Chlorophyll- } \\
\text { a }\end{array}$ & $\begin{array}{c}\text { Chlorophyll- } \\
\text { b }\end{array}$ & $\begin{array}{c}\text { Total } \\
\text { chlorophyll }\end{array}$ & \\
\hline $\mathbf{T}_{1}$ & 6.64 & 8.70 & 1.97 & 1.51 & 0.50 & 2.01 & 273.26 \\
\hline $\mathbf{T}_{2}$ & 6.17 & 9.61 & 2.01 & 1.48 & 0.49 & 1.97 & 228.76 \\
\hline$T_{3}$ & 5.79 & 8.28 & 1.81 & 1.43 & 0.46 & 1.89 & 255.15 \\
\hline $\mathbf{T}_{4}$ & 6.43 & 7.40 & 2.14 & 1.56 & 0.53 & 2.09 & 281.03 \\
\hline$T_{5}$ & 6.14 & 6.71 & 2.53 & 1.54 & 0.52 & 2.06 & 289.15 \\
\hline $\mathbf{T}_{6}$ & 6.76 & 5.13 & 2.72 & 1.56 & 0.51 & 2.07 & 311.73 \\
\hline $\mathbf{T}_{7}$ & 6.91 & 6.64 & 2.44 & 1.57 & 0.52 & 2.09 & 332.69 \\
\hline $\mathbf{T}_{8}$ & 7.45 & 5.58 & 2.72 & 1.64 & 0.54 & 2.18 & 346.08 \\
\hline $\mathbf{T}_{9}$ & 7.84 & 5.35 & 3.61 & 1.68 & 0.57 & 2.25 & 301.56 \\
\hline$T_{10}$ & 7.20 & 5.12 & 2.80 & 1.74 & 0.56 & 2.30 & 313.94 \\
\hline $\mathbf{T}_{11}$ & 7.53 & 4.32 & 3.04 & 1.67 & 0.55 & 2.22 & 343.34 \\
\hline $\mathbf{T}_{12}$ & 7.96 & 3.45 & 3.93 & 1.85 & 0.59 & 2.44 & 366.17 \\
\hline S. Em \pm & 0.10 & 0.10 & 0.04 & 0.03 & 0.01 & 0.04 & 1.24 \\
\hline CD@ 5\% & 0.30 & 0.30 & 0.12 & 0.09 & 0.03 & 0.12 & 3.71 \\
\hline
\end{tabular}

Table.2 Effect of chitosan foliar application on biochemical parameters of strawberry under naturally ventilated polyhouse

\begin{tabular}{|c|c|c|c|c|c|c|c|}
\hline Treatment & $\begin{array}{c}\text { Reducin } \\
\text { g } \\
\text { sugar } \\
(\%)\end{array}$ & $\begin{array}{c}\text { Non } \\
\text { reducing } \\
\text { sugar }(\%)\end{array}$ & $\begin{array}{c}\text { Total } \\
\text { sugar } \\
(\%)\end{array}$ & $\begin{array}{c}\text { Titratable } \\
\text { acidity } \\
(\%)\end{array}$ & $\begin{array}{c}\text { Ascorbic } \\
\text { acid } \\
(\mathrm{mg} / 100 \mathrm{~g})\end{array}$ & $\begin{array}{c}\text { Anthocyanin } \\
\text { (mg/100 g) }\end{array}$ & 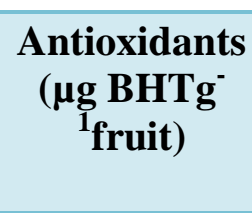 \\
\hline $\mathbf{T}_{1}$ & 3.84 & 1.49 & 5.33 & 1.21 & 42.69 & 36.94 & 290.23 \\
\hline $\mathbf{T}_{2}$ & 3.83 & 1.47 & 5.30 & 1.19 & 39.97 & 37.22 & 284.25 \\
\hline $\mathbf{T}_{3}$ & 3.54 & 1.43 & 4.97 & 1.37 & 37.93 & 37.81 & 267.70 \\
\hline $\mathbf{T}_{4}$ & 4.13 & 1.66 & 5.79 & 1.24 & 43.63 & 41.62 & 324.82 \\
\hline$T_{5}$ & 4.14 & 1.62 & 5.76 & 1.17 & 44.29 & 44.42 & 331.73 \\
\hline $\mathbf{T}_{6}$ & 4.41 & 1.52 & 5.93 & 0.94 & 46.04 & 46.42 & 357.40 \\
\hline $\mathbf{T}_{7}$ & 4.22 & 1.56 & 5.78 & 1.12 & 44.71 & 44.35 & 363.97 \\
\hline $\mathbf{T}_{8}$ & 4.36 & 1.49 & 5.85 & 1.10 & 48.68 & 44.17 & 378.14 \\
\hline$T_{9}$ & 4.79 & 1.65 & 6.44 & 0.97 & 48.48 & 48.66 & 413.42 \\
\hline$T_{10}$ & 4.62 & 1.64 & 6.26 & 0.86 & 53.29 & 54.69 & 384.37 \\
\hline$T_{11}$ & 4.37 & 1.50 & 5.87 & 1.01 & 52.82 & 48.46 & 396.15 \\
\hline$T_{12}$ & 4.34 & 1.54 & 5.88 & 0.87 & 51.60 & 54.26 & 412.26 \\
\hline S. Em \pm & 0.060 & 0.023 & 0.090 & 0.015 & 0.31 & 0.46 & 0.012 \\
\hline CD@ $@ 5 \%$ & 0.180 & 0.069 & 0.260 & 0.045 & 0.92 & 1.37 & 0.036 \\
\hline
\end{tabular}




\begin{tabular}{|c|c|}
\hline LEGEND & \\
\hline$T_{1}$ - Water spray at 45 DAP & $\mathrm{T}_{7}$ - Chitosan spray $2 \mathrm{gm} \mathrm{l}^{-1}$ at $45 \mathrm{DAP}$ \\
\hline$T_{2}$ - Water spray at 45 and 90 DAP & $\mathrm{T}_{8}$-Chitosan spray $2 \mathrm{gm} \mathrm{l}^{-1}$ at 45 and $90 \mathrm{DAP}$ \\
\hline$T_{3^{-}}$Water spray at 45,90 and 135 DAP & $\mathrm{T}_{9}$-Chitosan spray $2 \mathrm{gm} \mathrm{l}^{-1}$ at 45,90 and $135 \mathrm{DAP}$ \\
\hline $\mathrm{T}_{4^{-}}$Chitosan spray $1 \mathrm{~g} \mathrm{l}^{-1}$ at $45 \mathrm{DAP}$ & $\mathrm{T}_{10}$-Chitosan spray $3 \mathrm{gm} \mathrm{l}^{-1}$ at $45 \mathrm{DAP}$ \\
\hline $\mathrm{T}_{5^{-}}$Chitosan spray $1 \mathrm{~g} \mathrm{l}^{-1}$ at 45 and 90 DAP & $\mathrm{T}_{11}$-Chitosan spray $3 \mathrm{gm} \mathrm{l}^{-1}$ at 45 and $90 \mathrm{DAP}$ \\
\hline $\mathrm{T}_{6^{-}}$Chitosan spray $1 \mathrm{~g} \mathrm{I}^{-1}$ at 45,90 and 135 DAP & $\mathrm{T}_{12}$-Chitosan spray $3 \mathrm{gm} \mathrm{l}^{-1}$ at 45,90 and $135 \mathrm{DAP}$ \\
\hline
\end{tabular}

Fig.1 General view of the experimental plot

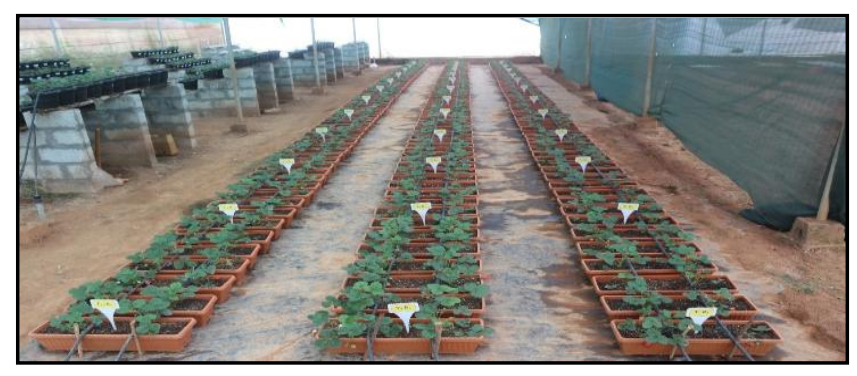

Fig.2 Influence of chitosan foliar application on fruit quality of strawberry

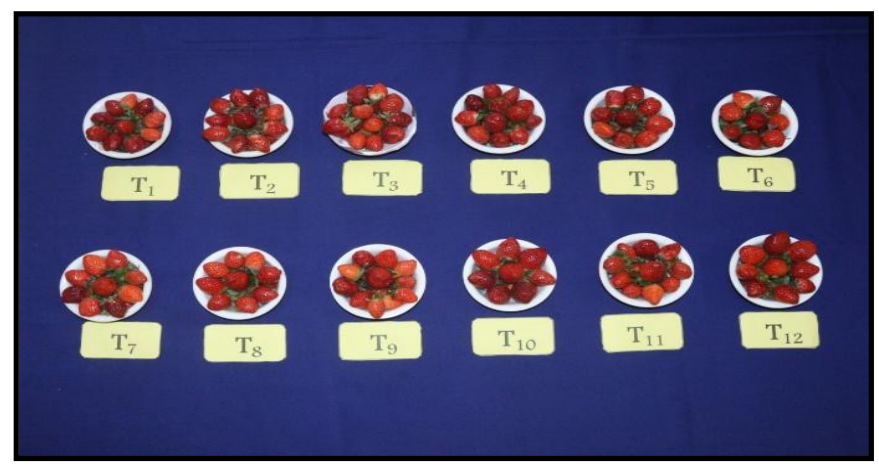

Fig.3 Effect of chitosan foliar application on antioxidants content of strawberry under naturally ventilated polyhouse

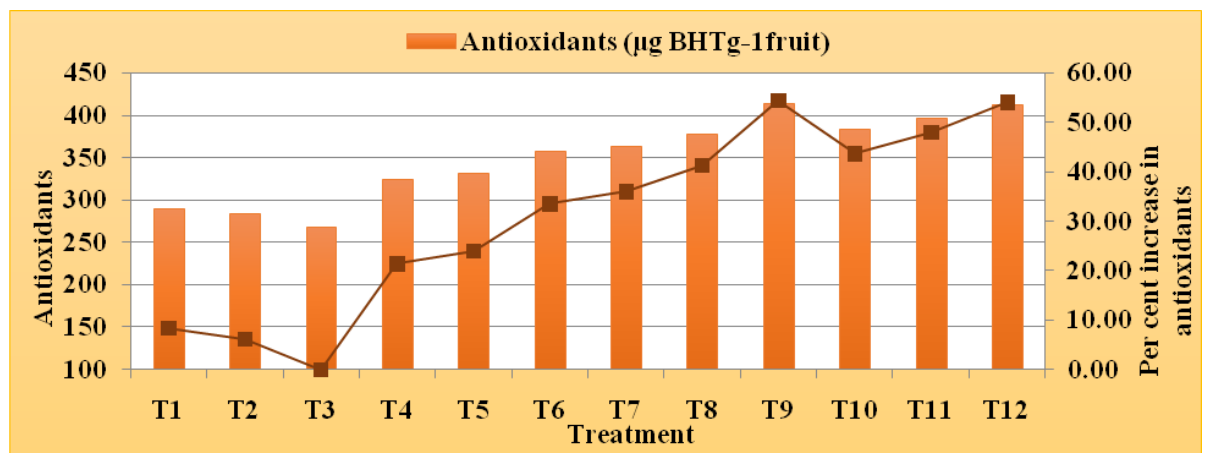


The possible reason for increase in shelf life of fruit was reduction in weight loss and spoilage by microbes might be due to reduced respiration and creating modified atmosphere within fruits as influenced by the presence of a layer of chitosan coating on the fruit surface resulting in increased the membrane integrity of fruits, so that the fruits could retain more water against the force of evaporation and possibly they might have also altered some of the proteinaceous constituents. The increased chlorophyll content might be due to exogenous chitosan treatment on leaf might alleviate abiotic stresses by increment in chlorophyll concentration, decreasing in stomatal and non-stomatal transpiration as well as improve water use efficiency. These results are in consistent with El-Tantaway (2009),

Chitosan application improved both reducing and non-reducing sugar content of fruit while decreased its acidic content, however the concentration effect is limited to $2 \mathrm{~g}^{-1}$. Among the different treatments tested, foliar application of chitosan $2 \mathrm{~g} \mathrm{l}^{-1}$ thrice at 45 days interval recorded significantly higher reducing sugar $(4.79 \%)$, non-reducing sugar $(1.65 \%)$, total sugar $(6.44 \%)$ and antioxidants (413.42 $\mu \mathrm{g}$ BHT $\mathrm{g}^{-1}$ fruit), antioxidants contents and per cent increase in antioxidant over water spray is shown in figure 3. While the maximum ascorbic acid $(53.29 \mathrm{mg} / 100 \mathrm{~g})$ and anthocyanin content $(54.69 \mathrm{mg} / 100 \mathrm{~g})$ and minimum titratable acidity $(0.86 \%)$ was recorded in treatment foliar application of chitosan $3 \mathrm{~g} \mathrm{l}^{-1}$ once after 45 days after planting. On the other hand, the lowest biochemical composition was noticed in water sprayed treatments (Table 2 and Fig. 2). These results are in agreement with those reported by Abdel-Mawgoud et al., (2010) who found that the quality and biochemical composition increased significantly in response to chitosan application compared to untreated water sprayed plants. These parameter's increased as the chitosan applied concentrations increased until $2 \mathrm{~g} \mathrm{l}^{-1}$ then the response started to decline but significantly higher than the untreated plants. The fruits obtained from chitosan treated plants having higher content of antioxidants because it imparts effects in terms of the maintenance of nutraceuticals and other phenolic compounds Petriccione et al., (2015). The similar results were also obtained by Romanzzi et al., (2015) and Rahman et al., (2018).

As against water spray, chitosan application also improved the yield levels. In that, concentration of 2 and $3 \mathrm{~g} \mathrm{l}^{-1}$ yielded 301-366 $\mathrm{g}$ plant $^{-1}$, while chitosan $3 \mathrm{~g}^{-1}$ applied at 45,90 and 135 days recorded maximum (366.17 $\mathrm{g} \mathrm{plant}^{-1}$ ) an increase of 60.07. The results are in line with the results obtained by Gornik et al., (2008) and Abdel-Mawgoud et al., (2010).

In conclusion the result of the present study revealed that cultivation of strawberry variety "winter dawn" by foliar application of chitosan@3g 1 at 45, 90 and 135 days after planting was found better for achieving not only yield levels of the fruit but also its quality parameters under naturally ventilated polyhouse.

\section{References}

Abdel-Mawgoud, A. M. R., Tantawy, T. A., El-Nemr, M. A. and Sassine, Y. N., 2010, Growth and yield responses of strawberry plants to chitosan application. European J. Sci. Res., 39(1): 170-177.

Bautista-Banos, S., M. Hernandez-Lopez, E. Bosquez-Molina and C.L. Wilson, 2003, Effects of chitosan and plant extracts on growth of Colletotrichum gloeosporioides, anthracnose levels and quality of papaya fruit. Crop Protect., 22: 1087-1092. 
Benhamou, N., Kloepper, J.W. and Tuzun, S., 1998. Induction of resistance against fusarium wilt of tomato by combination of chitosan with an endophytic bacterial strain: ultrastructure and cytochemistry of the host response. Planta., 204: 153168.

Cordenusi, B.R., Genovese, M.I., Nascimento, J.R.O., Hassimoto, N.M.A., Dos-Santos, R.J. and Lajolo, F.M., 2005, Effects of temperature on the chemical composition and antioxidant activity of three strawberry cultivars. Food Chem., 91: 113-121.

Dris, R. and Niskanen, R., 1999, Quality changes of Lobo apples during cold storage. Acta Hortic.,485: 125-133.

El-Ghaouth, A., Arul, J., Grenier, J. and Asselin, A., 1992, Antifungal activity of chitosan on two postharvest pathogens of strawberry fruits. Phytopathology. 82: 398-402.

El-Tantawy, E.M., 2009, Behaviour of tomato plants as affected by spraying with chitosan and amino fort as natural stimulator substances under application of soil organic amendments. Pak. J. Biol. Sci., 12: 1164-1173.

Fisher, R. R. and Yates, F., 1963, Stastical tables for biological, agricultural and medical research. Sixth edition, Oliver and Boyd, Tweedale Court, Edinberg, pp. 747-777.

Hadwiger, L.A., Klosterman, S.J. and CHOI, J.J., 2002, The mode of action of chitosan and its oligomers in inducing plant promoters and developing disease resistance in plants, In: K. Suchiva, S. Chandrkrachang, P. Methacanon and M.G. Peter (eds.), Advances in chitin science, vol. 5, Bangkok, pp: 452-457.

Hernandez-Munoz, P., Almenar, E., Ocio, M. J. and Gavara, R., 2006, Effect of calcium dips and chitosan coatings on postharvest life of strawberries (Fragaria $\times$ ananassa). Postharvest
Biol. Technol., 39(3): 247-253.

Jackson, D., Looney, N., Morley, B. and Thiele, G., 2011,Temperate and subtropical fruit production, pp 202-25.

Malerba, M. and Cerena, R., 2018, Recent advances of chitosan application in plant. Polymer. 10(2): 1-10.

Naeem, M. A., Hassan, M., Ahmed and ElSayed, A., 2010, Radiation-induced degradation of chitosan for possible use as a growth promoter in agricultural purposes. Carbohydr.Polym., 79: 555562.

Peniston, Q.P. and Johnson, E., 1980, Process for the manufacture of chitosan. US Patent No. 4, 195, 175, pp 5.

Petriccione, M., Mastrobuoni, F., Pasquariello, M. S., Zampella, L., Nobis, E., Guiseppecapriolo and MarcoScortichini., 2015, Effect of chitosan coating on postharvest quality and antioxidant enzyme system response of strawberry fruit during cold storage. $J$. food. mdpi.com. 8(4): 501-523.

Rahman, M., Mutka, J. A., Sabir, A. A. S. and Gupta, D. R., 2018, Chitosan biopolymer promotes yield and stimulates accumulation of antioxidants in strawberry fruit. Plosone, 13(9):1-14.

Romanazzi, G., Feliziani, E., Bautista-Banos, S. and Sivakumar, D., 2015, Shelf life extension of fresh fruit and vegetables by chitosan treatment. Crit. Rev. Food Sci. Nutr., doi:10.1080/ 10408398.2014.900474.

Sakif, T. I., Dobriansky, A., Russell, K. and Islam, T., 2016, Does chitosan extend the shelf life of fruits. Adv. Biosci. Biotechnol., 7: 337-342.

Sugiyama, H., K. Hisamichi, K. Sakai, T. Usui, J.I. Ishiyama, H. Kudo, H. Ito and Y. Senda, 2001, The conformational study of chitin and chitosan oligomers in solution. Bioorganic and Medicinal Chemistry, 9: 211-216.

$\mathrm{Yu}, \quad$ G. and Meuhlbauer, G., 2001, 
Benzothiadiazole-induced gene blight. Physiological and Molecular expression in wheat spikes does not Plant Pathology, 59: 129-139.

provide resistance to fusarium head

\section{How to cite this article:}

Nithin, K. M., D. Madaiah, B. S. Shivakumar, M. Dinesh Kumar and Dhananjaya, B. C. 2020. Influence of Chitosan Foliar Application on Quality and Biochemical Traits of Strawberry (Fragaria $\times$ ananassa Duch.) under Naturally Ventilated Polyhouse. Int.J.Curr.Microbiol.App.Sci. 9(09): 243-250. doi: https://doi.org/10.20546/ijcmas.2020.909.030 